\section{Visualization of looping involving the immunoglobulin heavy-chain locus in developing $B$ cells}

\author{
Camil Sayegh, ${ }^{1,3}$ Suchit Jhunjhunwala, ${ }^{1}$ \\ Roy Riblet, ${ }^{2}$ and Cornelis Murre ${ }^{1,4}$
}

${ }^{1}$ Division of Biological Sciences, University of California, San Diego, La Jolla, California 92093, USA; ${ }^{2}$ Torrey Pines Institute for Molecular Studies, San Diego, California 92121, USA

The immunoglobulin heavy-chain (IgH) locus undergoes large-scale contraction in B cells poised to undergo IgH V(D)J recombination. We considered the possibility that looping of distinct IgH $\mathrm{V}$ regions plays a role in promoting long-range interactions. Here, we simultaneously visualize three subregions of the IgH locus, using threedimensional fluorescence in situ hybridization. Looping within the IgH locus was observed in both $\mathrm{B}$ - and Tlineage cells. However, monoallelic looping of IgH V regions into close proximity of the IgH DJ cluster was detected in developing $B$ cells with significantly higher frequency when compared with hematopoietic progenitor or $\mathrm{CD8}^{+} \mathrm{T}$-lineage cells. Looping of a subset of IgH V regions, albeit at lower frequency, was also observed in RAG-deficient pro-B cells. Based on these observations, we propose that Ig loci are repositioned by a looping mechanism prior to $\mathrm{IgH} \mathrm{V}(\mathrm{D}) \mathrm{J}$ rearrangement to facilitate the joining of Ig variable, diversity, and joining segments.

Supplemental material is available at http://www.genesdev.org.

Received November 29, 2004; revised version accepted December 10, 2004.

Eukaryotic chromosomes are assembled into higher-order structures that are tightly packaged inside the nucleus. Recent evidence strongly suggests that these complex chromatin structures are both dynamic and critical for appropriate regulation of gene expression. The organization of chromatin into a repressive or permissive state is regulated by noncoding elements such as promoters, enhancers, insulators, locus control regions, and matrix attachment regions (Baxter et al. 2002; Felsenfeld and Groudine 2003). These cis-acting elements are selectively occupied by tissue- and stage-specific transcription factors that often serve as docking sites for chromatin remodeling factors. The precise mechanism regulating long-range interactions of cis-act-

[Keywords: Immunoglobulin heavy-chain; V(D)J rearrangement; locus contraction; long-range interactions; lymphocytes; E2A-deficient hematopoietic progenitors]

${ }^{3}$ Present address: Merck Frosst Center for Therapeutic Research, 16711 Trans Canada Hwy., Kirkland, Quebec H9H34, Canada

${ }^{4}$ Corresponding author.

E-MAIL murre@biomail.ucsd.edu; FAX (858) 534-7550.

Article and publication are at http://www.genesdev.org/cgi/doi/10.1101/ gad. 1254305 ing elements remains to be elucidated. Recently, a looping model, in which regulatory elements separated by relative long distances in the $\beta$-globin locus are brought into physical proximity, with the intervening DNA looping out, has been suggested to establish an open chromatin domain and to activate $\beta$-globin expression (Carter et al. 2002; Tolhuis et al. 2002; Ostermeier et al. 2003).

In $\mathrm{B}$ cells, the gene encoding the immunoglobulin heavy chain $(\mathrm{IgH})$ is assembled by combinatorial joining of variable $(\mathrm{V})$, diversity $(\mathrm{D})$, and joining $(\mathrm{J})$ DNA segments (Jones and Gellert 2004; Jung and Alt 2004). This process, known as $\mathrm{V}(\mathrm{D}) \mathrm{J}$ recombination, is critically dependent on the expression of the recombination activating genes 1 and 2 (RAG-1 and RAG-2) (Mombaerts et al. 1992; Shinkai et al. 1992). In-frame IgH V(D)J rearrangements leads to the formation of the pre-B-cell receptor. Pre-BCR-mediated signaling inhibits RAG gene expression, preventing further IgH gene rearrangement. B cells at this stage undergo rapid cellular expansion, ultimately followed by growth arrest, induction of RAG gene expression, and Ig light-chain (IgL) gene rearrangement. Once a productive IgL chain has been formed, RAG gene expression and IgL rearrangements are inhibited in the absence of auto-reactivity.

Both the IgH and IgL loci span a large region, which, in principle, forms a mechanistic barrier for efficient Ig rearrangement. Elegant studies, using three-dimensional (3D) fluorescent in situ hybridization analysis have shown that Ig gene rearrangement correlates with alterations in the nuclear location of the IgH locus. Both $\mathrm{IgH}$ alleles are localized in the proximity of the nuclear membrane in non-B-lineage cells. In contrast, in B cells, the IgH locus is relocated to the center of the nucleus, where it also undergoes large-scale condensation (Kosak et al. 2002).

Rearrangement of the IgH gene is tightly regulated by the combined activities of various transcription factors, including E2A, Pax5, and EBF (Romanow et al. 2000; Fuxa et al. 2004; Seet et al. 2004). E2A and EBF have been shown to act in concert with RAG proteins to activate IgH DJ gene rearrangement when overexpressed in nonlymphoid cells (Romanow et al. 2000; Goebel et al. 2001). Furthermore, EBF has been shown to directly or indirectly promote IgH $\mathrm{V}(\mathrm{D}) \mathrm{J}$ recombination upon enforced expression in E47-deficient hematopoietic progenitor cells (Seet et al. 2004). B-cell development in Pax5 -deficient mice is blocked at an early stage and show impaired distal V-region usage (Urbanek et al. 1994; Schebesta et al. 2002; Hesslein et al. 2003; Fuxa et al. 2004). Additionally, recent studies have indicated that Pax-5 acts to promote long-range contraction of the $\mathrm{IgH}$ locus in B cells poised to undergo IgH V(D)J gene rearrangement (Fuxa et al. 2004). Here, we visualize three domains present in the IgH locus, using 3D fluorescence in situ hybridization. We detect looping of the IgH locus in developing B cells involving the juxtaposition of IgH V regions into proximity of the $\mathrm{IgH} \mathrm{D} / \mathrm{J}$ regions. Interestingly, looping of $\mathrm{V}$ regions was also observed in RAGdeficient pro-B cells. These data indicate that in developing $\mathrm{B}$ cells, IgH V regions loop in the proximity of the IgH D/J cluster prior to the onset of Ig gene recombination. We propose that prior to Ig gene rearrangement, Ig loci are repositioned by a looping mechanism to facilitate joining of Ig gene segments. 
A

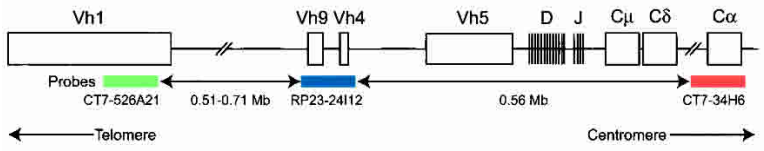

B

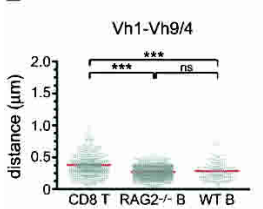

C

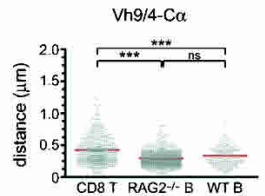

D

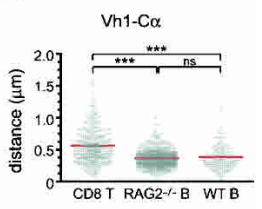

$\mathbf{E}$

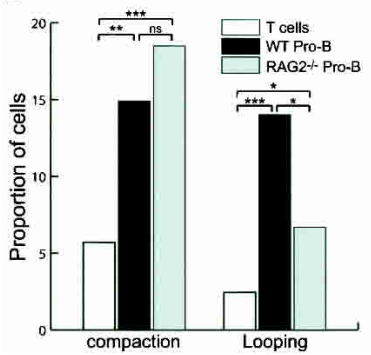

Figure 1. Compaction of distinct subregions of the $\mathrm{IgH}$ locus. $(A)$ The murine $\mathrm{IgH}$ locus and positions of the three BAC probes are indicated (not drawn to scale). The distances separating each of the three BAC probes-CT7-526A21, CT7-34H6, and RP23-24I12-and their positions within the IgH locus were determined using the Ensembl mouse genome database. Note that the exact location of the CT7-526A21 BAC remains to be determined. The colors of the three probes are shown as follows: CT7-526A21 (green), RP23-24I12 (blue), and CT7-34H6 (red). (B-D) Scatter-plots of the distances separating the $\mathrm{V}$ and $\mathrm{C} \alpha$ regions in $\mathrm{T}$ cells, in vitro-cultured wild-type, and RAG2deficient pro-B cells. $Y$-axis indicates distances separating the loci in microns. Red line indicates the average distance in each group. $\left(^{\star \star \star}\right)$ Significant difference $(p<0.0001)$ of the averages compared with that obtained from T-lineage cells. (E) Proportion of cells ( $Y$-axis) in which the IgH locus is compacted or in a looping configuration in $\mathrm{T}$ cells (white), wild-type pro-B cells (black), or RAG2 $2^{-/-}$pro-B cells (gray). (nd) Not determined $\left.\left.;{ }^{\star}\right) p<0.05 ;{ }^{\star \star}\right) p<0.01$.

\section{Results and Discussion}

\section{Long-range 3D complexity in lymphocytes}

The murine IgH locus spans over $3 \mathrm{Mb}$ of DNA, containing an estimated $200 \mathrm{~V}$ segments, $16 \mathrm{D}$ segments, and four J segments. The V segments have been grouped in 15 families based on sequence identity (Mainville et al. 1996). The largest family, Vh1 (J558), contains at least $100 \mathrm{~V}$ members, occupies $\sim 1 \mathrm{Mb}$ of DNA, and is located in the D-distal half of the $\mathrm{V}$ region. The Vh4 and Vh9 (gam3-8 and X-24) region is located $\sim 560 \mathrm{~kb}$ upstream of Ig C $\alpha$ (Chevillard et al. 2002; Fig. 1A). To explore the mechanisms contributing to the large-scale contraction of the IgH locus observed in developing B cells (Baxter et al. 2002; Kosak et al. 2002), four-color 3D immunofluorescence in situ hybridization (3D FISH) was used to directly visualize three regions of the IgH locus. Three specific BAC probes were simultaneously used to label the $3^{\prime}$ region of $\mathrm{Vh} 1$ (green), the Vh 4 and $\mathrm{Vh} 9$ (Vh9/4) region (blue), and the Ig C $\alpha$ exons (red) (Fig. 1A). Lamin-specific antibodies were used to label the nuclear membrane (gray).

Four cell types were used in the following experiments: in vitro expanded pro-B cells derived from either wild-type mice or RAG2-deficient mice, in vitro-activated $\mathrm{CD}^{+}$splenic $\mathrm{T}$ cells, and E2A-deficient hematopoietic progenitor cells. Nuclei were hybridized with the Ig specific probes and analyzed by deconvolution microspcopy. A fraction of nuclei derived from pro-B cells did not show hybridization to either the $\mathrm{Vh} 9 / 4$ or to both Vh1 and Vh9/4 probes. These were most likely derived from pro-B cells that had completed IgH V(D)J rearrangement, since such nuclei were not observed in RAG $^{-1-}$ pro-B cells and T cells (data not shown). Only cells in which all three signals could be detected from both alleles were included in the analysis. To precisely calculate the distances separating each probe, the $3 \mathrm{D}$ coordinates of the center of mass of each probe were obtained by fitting each signal in each $z$-section into a polygon (Fig. 2D,G,J,M). Note that often only one out of two $\mathrm{IgH}$ allele are shown because of the optical sectioning. Polygons obtained for each probe were then interpolated into a 3D object for which the coordinates of the center of mass were calculated. This analysis revealed striking features of the interphase organization of the $\operatorname{IgH}$ locus in the various cell types.

The distances separating the $\mathrm{Vh} 1$ and $\mathrm{Vh} 9 / 4$ regions were significantly reduced in wild-type and RAG2-deficient pro-B cells $(p<0.001)$, representing a $41 \%$ and $31 \%$
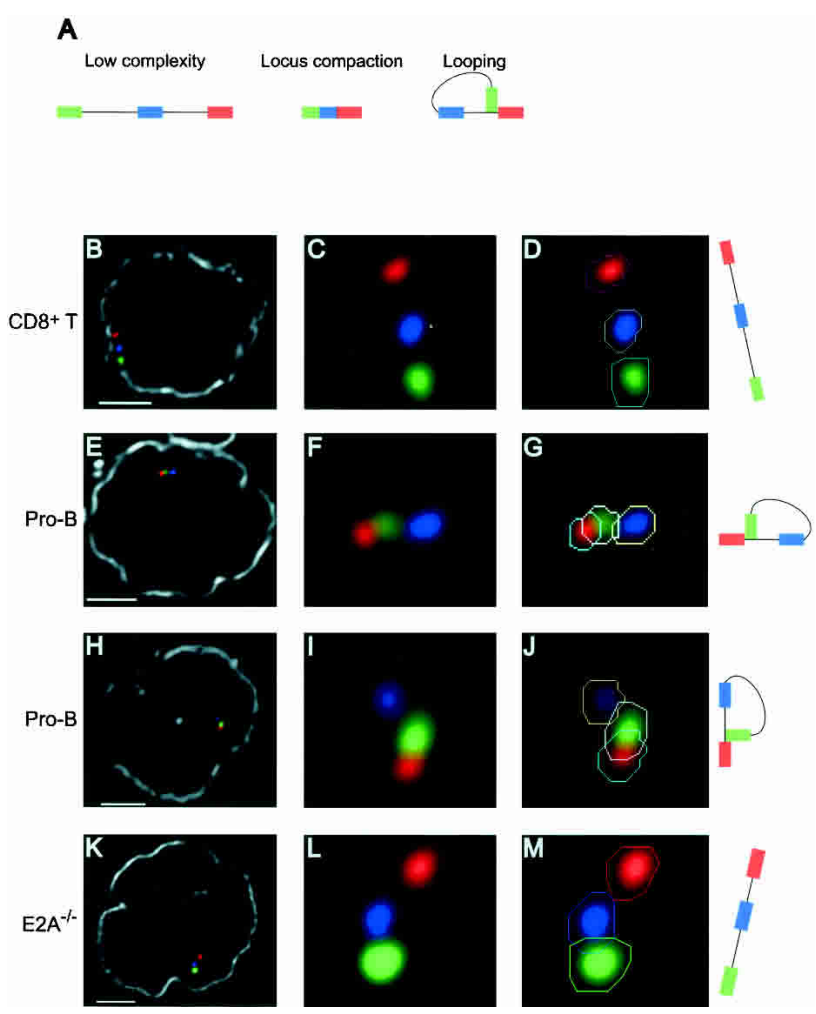

Figure 2. Looping involving the distal IgH Vhl and the $\mathrm{C} \alpha$ regions. (A) Schematic diagram of three possible distinct IgH configurations. $(B-M)$ Three-dimensional configuration of the IgH locus resolved using four-color FISH. Digitally magnified pictures of IgH alleles are shown. Polygons (in one selected z-section) that were used to identify the coordinates of the center of mass for each signal are indicated $(D, G, J, M)$. The nuclear membrane stained using lamin antibodies is shown in gray $(B, E, H, K)$. Bar, $2 \mu \mathrm{m} .(B-D) \operatorname{IgH}$ locus in $\mathrm{CD}^{+} \mathrm{T}$ cells. $(E-J)$ Looping involving the Vhl and the $\mathrm{C} \alpha$ region in wild-type pro-B cells. $(K-M)$ Configuration of the IgH locus in E2Adeficient hematopoietic progenitor cells. 
Sayegh et al.

contraction, respectively, when compared with the distance separating these probes in T cells (Fig. 1B; Table 1). Additionally, a significant long-range contraction $(p<0.001)$ of the average distance separating the Vh9/4 and $\mathrm{C} \alpha$ regions was observed in wild-type $(27 \%)$ and RAG2-deficient pro-B cells $(46 \%)$ when compared with that of T-lineage cells (Fig. 1C; Table 1). Consistently, we observed a smaller proportion of $\mathrm{IgH}$ alleles in pro-B cells showing distances $>0.4 \mu \mathrm{m}$ and an increase in the frequency of alleles showing a distance between 0 and $0.2 \mu \mathrm{m}$ when compared with $\mathrm{CD}^{+} \mathrm{T}$ cells (Supplementary Fig. S1). Additionally, the relative distribution of distances separating each of the three regions appeared equally scattered in pro-B cells and T cells, suggesting that the $\mathrm{IgH}$ locus undergoes contraction in most pro-B cells (Supplementary Fig. S2).

It could be argued that IgH locus contraction in pro-B cells was caused by nuclear size differences. To address this question, the nuclear diameter of the cells was examined. The diameter of $\mathrm{CD}^{+} \mathrm{T}$ cells and pro-B cells derived from RAG-deficient mice is comparable, $7.47 \pm 1.00$ and $7.74 \pm 0.83 \mu \mathrm{m}$ respectively. In contrast, the diameter of wild-type pro-B cells was significantly reduced to $5.72 \pm 0.62 \mu \mathrm{m}$ when compared with pro-B cells derived from RAG-deficient mice or $\mathrm{CD}^{+} \mathrm{T}$ cells (Supplementary Table S1). To determine whether contraction of the IgH locus in pro-B cells derived from wildtype mice is caused by a reduction in nuclear size, we measured the distances separating two control probes, RP23-132L4 and RP23-478G17, located opposite of the Igh locus, at $12 \mathrm{~A} 1.3$ on the arm of chromosome 12 . We note that the region delineated by the two control probes comprises at least one housekeeping gene (Supplementary Fig. S3). Interestingly, the distances separating these loci, on average $1.76 \mathrm{Mb}$ per $\mu \mathrm{m}$, were equivalent in all three cell types (Supplementary Table S1). Taken together, these data indicate that locus contraction in developing $B$ cells is not a general property of pro-B-cell nuclei.

If the spatial organization of the IgH locus were to be linear, then it would be expected that the sum of the distances separating the Vh1 and Vh9/4 probes and Vh9/4 and $\mathrm{C} \alpha$ probes would be equal to the distances
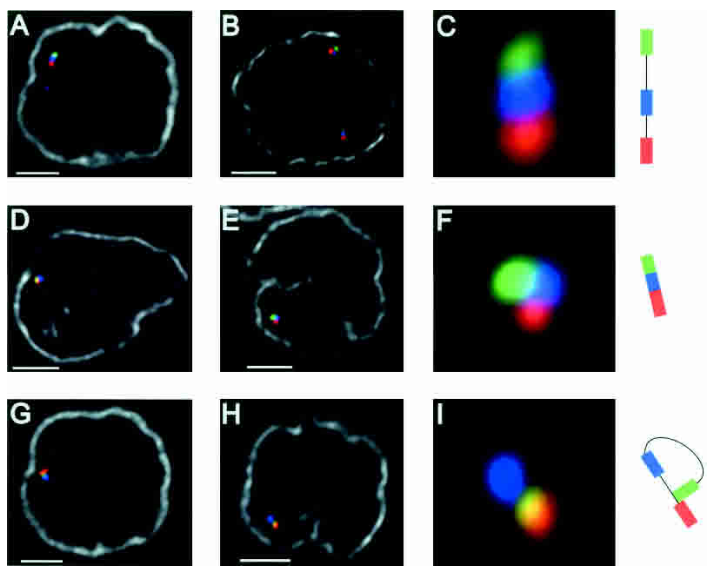

Figure 3. Looping involving the IgH locus in RAG-deficient pro-B cells. Three distinct configurations of the $\operatorname{IgH}$ locus were detected Three-dimensional FISH in nuclei derived RAG deficient pro-B cells. $(A-C)$ Low-complexity. $(D-F)$ Locus compaction. $(G-I)$ Looping. The nuclear membrane is shown in gray. Bar, $2 \mu \mathrm{m}$. separating the Vh1 and $\mathrm{C} \alpha$ regions. However, in all cell types analyzed, the distance separating the Vh1-C $\alpha$ probes was substantially less than predicted from a linear configuration (Fig. 1D; Table 1). Taken together, these observations indicate that the $\mathrm{IgH}$ chain gene locus displays long-range 3D complexity in both $\mathrm{T}$ and $\mathrm{B}$ lymphocytes.

\section{Condensation of the IgH locus in lymphoid cells}

Two possible configurations that can account for longrange 3D complexity, locus compaction, and looping were distinguished from the low-complexity configuration and examined in detail (Fig. 2A). Both of the observations presented here and in previous studies showed large-scale contraction of the IgH locus in developing B cells (Kosak et al. 2002). To examine whether the reduction in distances reflects chromatin condensation, we used the following numerical criteria. Locus compaction was defined when the distance separating the Vh1 from the Vh9/4 regions was $<0.2 \mu \mathrm{m}$ and the distance separating Vh1 and $\mathrm{C} \alpha$ was $<0.25 \mu \mathrm{m}$, representing at least a 2.5 -fold contraction. Using these criteria, our analysis revealed that $5.7 \%$ of the $\mathrm{CD} 8^{+} \mathrm{T}$ cells contained alleles in a compacted conformation (Fig. 1E). In contrast, pro-B cells derived from RAG-deficient or wild-type mice contained significantly more alleles in a compacted state, the frequency being $18.5 \%$ and $14.9 \%$, respectively (Figs. 1E, 3D-F). We note that we cannot rule out the possibility that wild-type pro-B cells contained alleles in which recombination occurred downstream of the Vh9/4 region.

\section{Looping involving the IgH locus in developing $B$ cells}

Upon visualizing the $\mathrm{IgH}$ locus in nuclei derived from pro-B cells and $\mathrm{CD}^{+} \mathrm{T}$, we observed a substantial fraction of alleles, $24.6 \%$ and $19.6 \%$, respectively, showing the Vh1 (labeled in green) region in closer proximity to the $\mathrm{C} \alpha$ (labeled in red) region relative to the Vh9/4 (labeled in blue) region. This observation suggested the presence of looped $\mathrm{IgH}$ domains in a large fraction of both B- and T-lineage cells (Supplementary Fig. S4). Interestingly, closer examination revealed that, in contrast to $\mathrm{CD}^{+} \mathrm{T}$ cells, a substantial proportion of looped $\mathrm{IgH}$ alleles derived from wild-type pro-B cells showed the Vh1 and $\mathrm{C} \alpha$ regions (labeled with green and red, respectively) localized in close proximity, with the two signals often overlapping, whereas the Vh9/4 (labeled in blue) region was distinctly separated (Fig. 2A,E-J).

In order to quantitatively determine the degree of looped structures in which the Vh1 regions was localized in close proximity to the $\mathrm{C} \alpha$ region and the IgH DJ cluster, we used the following numerical criteria: (1) The distance separating Vh1 and $\mathrm{C} \alpha$ is $<0.2 \mu \mathrm{m}$, corresponding to $\sim 250 \mathrm{~kb}$. The latter is determined from the distance separating the $\mathrm{Vh} 9 / 4$ from the $\mathrm{C} \alpha$ region, estimated at $1.28 \mathrm{Mb} / \mu \mathrm{m}$, measured in $\mathrm{CD}^{+} \mathrm{T}$ cells, which represent a cell type in which the IgH locus is present in relatively "low-complexity uncompacted" 3D configuration. We note that the distance separating the IgH D cluster from the IgH C $\alpha$ exons is $\sim 200 \mathrm{~kb}$. Thus, $0.2 \mu \mathrm{m}$ is consistent with localization of the Vh1 region in proximity to the IgH D cluster. (2) The distance separating Vh9/4 and $\mathrm{C} \alpha$ is greater than the distance separating Vh1 and $\mathrm{C} \alpha$ by at least $0.15 \mu \mathrm{m}$. Using these criteria, looping 
Table 1. Distances separating the IgH subregions, Vh1, Vh9/4, and C $\alpha$ in pro-B cells, RAG-deficient pro-B cells, CD8 $8^{+}$T cells, and in E2A-deficient hematopoietic progenitor cells

\begin{tabular}{lcccr}
\hline & Pro-B & RAG2 $^{-/-}$ & CD8 $^{+} \mathrm{T}$ & $\mathrm{E}^{-1-}$ \\
\hline$n$ & $114^{+}$ & 372 & 245 & 200 \\
Vh1-Vh9/4 & $0.29 \pm 0.14^{\star \star \star}$ & $0.27 \pm 0.11^{\star \star \star}$ & $0.38 \pm 0.20$ & $0.33 \pm 0.15$ \\
Vh9/4-C $\alpha$ & $0.33 \pm 0.19^{\star \star \star}$ & $0.29 \pm 0.12^{\star \star \star}$ & $0.42 \pm 0.23$ & $0.42 \pm 0.23$ \\
Vh1-C $\alpha$ & $0.38 \pm 0.21^{\star \star \star}$ & $0.37 \pm 0.14^{\star \star}$ & $0.56 \pm 0.28$ & $0.51 \pm 0.24$ \\
Vh1-Vh9/4+Vh9/4-C $\alpha$ & $0.62 \pm 0.25$ & $0.56 \pm 0.17$ & $0.81 \pm 0.31$ & $0.74 \pm 0.28$ \\
\hline
\end{tabular}

Shown are averages \pm SD expressed in microns. $(n)$ The number of cells analyzed for each cell type. $(+)$ Some cells may have undergone Ig $\mathrm{V}(\mathrm{D}) \mathrm{J}$ recombination. $\left(^{\star \star \star}\right) p<0.001$ when compared with $\mathrm{CD} 8^{+} \mathrm{T}$ cells.

was observed in $\sim 14 \%$ of interphase nuclei of pro-B cells (Figs. 1E, 2E-J). We note that such loops occurred monoallelically (Supplementary Table S2). Using a BAC probe located at the telomeric border of the Vh1 region, we observed that this region also underwent looping in developing $\mathrm{B}$ cells, indicating that different Vh1 regions have the ability to form loops with DNA segments located in the proximity of the $\operatorname{IgH~C} \alpha$ domain (data not shown).

Using the numerical criteria described above, such loops were also detected in interphase nuclei of CD8 T-lineage cells (Fig. 1E). However, the frequency of loops in $\mathrm{T}$ cells was significantly lower, $2.4 \%$ versus $14.0 \%$, respectively, when compared with the one observed in pro-B cells $(p<0.0001)$ (Fig. 1E). Similarly, loops in E2Adeficient hematopoetic progenitor cells were detected at low frequency $(1.5 \%$, C. Sayegh, unpubl.). Taken together, these observations demonstrate that loops involving IgH V regions and DNA segments localized in close proximity to the IgH DJ cluster can be detected with relatively high frequency in developing B cells.

\section{IgH locus undergoes looping in RAG-deficient B-lineage cells}

In vitro studies have demonstrated that the RAG proteins have the ability to recruit recombination substrates into a synaptic complex. In this complex, RAG-mediated DNA double-stranded breaks are introduced and the broken ends subsequently fused by general DNA repair mechanisms (Eastman et al. 1996; Steen et al. 1996). Synapse formation has not been directly observed in B-lineage cells. Nevertheless, if such complexes occurred, then recruitment of $\mathrm{V}$ segments belonging to the $\mathrm{Vh} 1$ family into synaptic complexes could give rise to loop structures as detected by our assay. To determine whether looping of the Vh1 region occurs as a consequence of RAG-mediated synapse formation during $\mathrm{IgH}$ V-DJ rearrangement, we analyzed the $3 \mathrm{D}$ organization of the IgH locus in interphase nuclei derived from RAG2deficient pro-B cells.

Interestingly, the fraction of pro-B nuclei derived from RAG2-deficient mice exhibiting looped alleles (6.7\%), while significantly lower than that found in wild-type pro-B cells $(p=0.0197)(14.0 \%)$, was significantly greater than the fraction observed in $\mathrm{CD}^{+} \mathrm{T}$ cells $(p=0.0224)$ $(2.4 \%)$ (Figs. 1E, 3G-I). It is conceivable that the difference in the proportion of looped alleles observed in wildtype pro-B cells and RAG2 $2^{-/-}$pro-B cells is caused by the absence of D-J joints, which normally precede IgH rearrangement and/or by the deficiency in RAG activity. Nevertheless, these observations indicate that looping in the IgH locus occurs in B cells, poised to undergo rearrangement, even in the absence of RAG activity.

\section{Looping of Ig variable regions in developing B cells}

Recent studies have begun to elucidate the mechanisms by which long-range interactions of cis-regulatory elements promote the regulation of gene expression. A model has been proposed for the developmental regulation of expression of $\beta$-globin genes, where the repressive chromatin state is maintained by attaching regulatory regions to the nuclear matrix, thus preventing long-range promoter-enhancer interactions (Ostermeier et al. 2003). Activation of gene expression would require the expression of specific transcription factors, the acetylation of histones at hypersensitive sites, and finally, the clustering of distally located regulatory regions through a looping mechanism. The extended structure of the $\operatorname{IgH~V}$ region, encompassing $\sim 2 \mathrm{Mb}$ of DNA, is a potential barrier to the efficient synapsis and rearrangement of distally located elements. In support of this, Alt and colleagues have proposed a chromosomal proximity hypothesis, stating that the rearrangement mechanism preferentially favors genes that are in close proximity (Yancopoulos et al. 1984; Yancopoulos and Alt 1986). This is best demonstrated in pro-B cells derived from IL7R-deficient mice where a gradient of usage of $\mathrm{V}$ elements is observed; D-proximal $\mathrm{V}$ elements rearranging normally, whereas usage of D-distal V-segments is impaired (Chowdhury and Sen 2001). Such a mechanism has also been proposed to regulate rearrangement of the T-cell receptor $\beta$ gene (Spicuglia et al. 2002). We propose that, similar to the regulation of $\beta$-globin gene expression, looping presents a mechanism by which elements that are physically separated by large distances are brought into proximity during Ig gene rearrangement.

Our observations indicate that in both B- and T-lineage cells, loops within the IgH locus can be detected with relative high frequency. However, the frequency of loops involving IgH V regions that are located in close proximity to the IgH DJ cluster is significantly higher in $\mathrm{B}$ cells as compared with T-lineage cells. Based on these observations, we propose that the IgH locus is organized in both B and T cells in looped-like structures. Prior to the onset of $\mathrm{IgH}$ gene rearrangements, $\mathrm{IgH} \mathrm{V}$-region segments are moved into close proximity of the DJ cluster to promote $\operatorname{IgH} \mathrm{V}(\mathrm{D}) \mathrm{J}$ gene rearrangement.

Our observations also demonstrate that looping into close proximity of the IgH DJ cluster is monoallelic. It is conceivable that monoallelic looping contributes to allelic exclusion (Bergman and Cedar 2004). However, we note that our observations do not exclude the possibility 
that IgH V regions, distinct from the IgH Vhl, undergo looping on the second allele.

How are such loops organized and formed? It is plausible that looping of distinct Ig Vh regions may require the interactions of specific matrix attachement region (MAR)-binding proteins with MARs that are interspersed in the IgH locus (Goebel et al. 2002). Alternatively, reorganization of a matrix to which the IgH locus is tethered may regulate looping. It should now be possible using the strategy described here to examine how Ig loops are formed and how they are regulated.

\section{Materials and Methods}

\section{Mice and cell culture}

All mice used were maintained onto a C57BL/6 background. Pro B cells were generated from femoral bone marrow suspensions by positive enrichment of $\mathrm{B}_{2} 2 \mathrm{O}^{+}$cells using magnetic separation (Miltenyi biotec) and cultured for 3-4 d in Optimem medium containing $10 \%$ fetal calf serum, $200 \mathrm{U} / \mathrm{mL}$ penicillin, $200 \mu \mathrm{g} / \mathrm{mL}$ streptomycin, $4 \mathrm{mM} \mathrm{L}$-glutamine, and $50 \mu \mathrm{M} \beta$-mercaptoethanol supplemented with IL-7 and SCF at $2 \mathrm{ng} / \mathrm{mL}$. $\mathrm{CD}^{+} \mathrm{T}$ cells were isolated form splenic cell suspensions by positive enrichment of $\mathrm{CD}^{+}$cells using magnetic separation. Cells were plated at $0.1 \times 10^{6}$ cells $/ \mathrm{mL}$ in 24 -well plates previously coated with anti-CD3 $\varepsilon$ antibody (2C11) and cultured for $3 \mathrm{~d}$ in RPMI 1640 containing $10 \%$ fetal calf serum, $200 \mathrm{U} / \mathrm{mL}$ penicillin, $200 \mu \mathrm{g} / \mathrm{mL}$ streptomycin, and $4 \mathrm{mM}$ L-glutamine to which anti-CD28 antibodies were added. E2A $\mathrm{A}^{-/-}$hematopoietic progenitors were grown as described previously (Ikawa et al. 2004).

\section{$3 D$ immuno FISH}

Approximately $40 \mu \mathrm{L}$ of a $1 \times 10^{6}$ cells $/ \mathrm{mL}$ suspension of cells grown in vitro was directly attached to coverslips. Cells were fixed in $4 \%$ paraformaldehyde for $10 \mathrm{~min}$ at room temperature (RT). Coverslips were treated with $0.1 \mathrm{M}$ Tris- $\mathrm{Cl}(\mathrm{pH} 7.2)$ for $10 \mathrm{~min}$ at $\mathrm{RT}$ and the cells were subsequently washed in $1 \times$ PBS. Cells were permeabilized for $10 \mathrm{~min}$ at RT with $1 \times$ PBS $+0.1 \%$ Triton X-100 $+0.1 \%$ saponin (WB1), and then incubated in $20 \%$ glycerol $1 \times$ PBS solution for $20 \mathrm{~min}$. Coverslips were immersed in liquid nitrogen and allowed to thaw at RT. Two additional freeze-thaw cycles were performed. Coverslips were then washed once in $1 \times \mathrm{PBS}$ and incubated at $37^{\circ} \mathrm{C}$ in $1 \times \mathrm{PBS}, 0.1 \%$ Triton $\mathrm{X}-100,5 \%$ bovine serum albumin (BB1). The nuclear membrane was stained using antiLamin A and B-specific antibodies (Santa Cruz) diluted to $2 \mu \mathrm{g} / \mathrm{mL}$ in BB1 for $30 \mathrm{~min}$ at $37^{\circ} \mathrm{C}$. Coverslips were washed twice in WB1 for $10 \mathrm{~min}$ at RT. Cells were then incubated for $30 \mathrm{~min}$ at $37^{\circ} \mathrm{C}$ with biotinylated goat-specific donkey antibodies (Jackson Immunoresearch) diluted to 30 $\mu \mathrm{g} / \mathrm{mL}$ in BB1 supplemented with normal donkey serum to a $5 \% \mathrm{v} / \mathrm{v}$ concentration. Coverslips were washed twice in WB1 for $10 \mathrm{~min}$ at RT and once in $1 \times$ PBS. Cells were subsequently fixed in a $2 \%$ PFA in $1 \times$ PBS solution for $10 \mathrm{~min}$ at RT. Coverslips were treated for $5 \mathrm{~min}$ in $0.1 \mathrm{M}$ Tris- $\mathrm{Cl}$ ( $\mathrm{pH} 7.2)$, and then washed once in $1 \times$ PBS. Cells were incubated in a $0.1 \mathrm{~N} \mathrm{HCl}$ solution for $30 \mathrm{~min}$ at RT, washed once in $1 \times \mathrm{PBS}$, and treated with 0.1 ? g/L DNase-free RNase in BB1 for $1 \mathrm{~h}$ at $37^{\circ} \mathrm{C}$. Coverslips were washed once in $1 \times$ PBS and in a $1 \times$ PBS, $0.5 \%$ Triton X-100, $0.5 \%$ saponin for $30 \mathrm{~min}$ at RT. Coverslips were then washed once in $1 \times$ PBS. The genomic DNA was denatured by incubating coverslips at $73^{\circ} \mathrm{C}$ in $2 \times$ SSC, $70 \%$ formamide solution for 2-1/2 min, followed by a 1-min incubation in $2 \times$ SSC, $50 \%$ formamide. Excess liquid was then rapidly dabbed and $10 \mu \mathrm{L}$ of hybridization cocktail was added to each coverslip. Coverslips were mounted on slides, sealed with rubber cement, and incubated overnight at $37^{\circ} \mathrm{C}$. In all experiments, the hybridization cocktail contained $400 \mathrm{ng}$ of each labeled probe, $4 \mu \mathrm{g}$ of mouse $\mathrm{C}_{0} \mathrm{t}$ DNA, $1 \mu \mathrm{g}$ of sheared salmon-sperm DNA in $50 \%$ formamide, $2 \times$ SSC, $10 \%$ dextran sulfate. The probes were denatured for $5 \mathrm{~min}$ at $70^{\circ} \mathrm{C}$ and chilled on ice prior to their addition to the coverslips. BAC CT7-526A21 and CT7-34H6 were labeled using a nick-translation kit (Roche) with alexa-fluor 488-5 dUTP and alexa-fluor 568-5 dUTP, respectively (molecular probes). BAC RP23-24I12 was labeled with a digoxigenin (DIG) nick-translation kit (Roche). On the following day, coverslips were delicately removed from the slides, and then washed once in $2 \times$ SSC, $50 \%$ formamide for $15 \mathrm{~min}$, and three times in $2 \times \operatorname{SSC} 5 \mathrm{~min}$ each at $37^{\circ} \mathrm{C}$. Coverslips were then incubated in $2 \times$ SSC, $3 \%$ BSA, $0.1 \%$ Tween-20 (BB2) for $30 \mathrm{~min}$ at RT. Dig-labeled probes and lamin antibodies were detected by incubating the cells with Cy5-conjugated mouse anti-DIG antibodies (Jackson Immunoresearch) at $20 \mu \mathrm{g} / \mathrm{mL}$ and Marina blue-conjugated neutravidin (Molecular probes) at $10 \mu \mathrm{g} / \mathrm{mL}$ in BB2 supplemented with normal mouse serum to $3 \% \mathrm{v} / \mathrm{v}$ for $30 \mathrm{~min}$ at $37^{\circ} \mathrm{C}$. Following this, coverslips were washed twice in $2 \times$ SCC $+0.1 \%$ Tween- 20 for 10 min each and once in $1 \times$ PBS at RT. Excess PBS was gently wiped out and coverslips mounted on slides.

Image acquisitions, distance calculations, and statistics

Images were captured with a DeltaVision deconvolution microscope system (Applied Precision, Inc.) located at the UCSD cancer center microscope facility. Using a 100× (NA 1.4) lens, images of $\sim 40$ serial optical sections, spaced by $0.2 \mu \mathrm{m}$, were acquired. The data sets were deconvolved and optical sections merged to produce 3D pictures using SoftWorx software (Applied Precision, Inc) on a Silicon Graphics Octane workstation. The 3D coordinates of the center of mass of each probe were input into Microsoft Excel, and the distances separating each probe were calculated using the equation

$$
\sqrt{\left(\mathrm{X}_{\mathrm{a}}-\mathrm{X}_{\mathrm{b}}\right)^{2}+\left(\mathrm{Y}_{\mathrm{a}}-\mathrm{Y}_{\mathrm{b}}\right)^{2}+\left(\mathrm{Z}_{\mathrm{a}}-\mathrm{Z}_{\mathrm{b}}\right)^{2}}
$$

where $\mathrm{X}, \mathrm{Y}$, and $\mathrm{Z}$ are the coordinates of object $\mathrm{a}$ or $\mathrm{b}$. In order to assess the different $3 \mathrm{D}$ structures, specific logical commands were written in Excel to specify each structure: (1) Locus compaction $=\mathrm{AND}$ (distance Vh1 to Vh $9 / 4<0.2 \mu \mathrm{m}$, distance Vh1 to $\mathrm{C} \alpha<0.25 \mu \mathrm{m})$. (2) Looping = AND/distance Vh1 to $\mathrm{C} \alpha<0.2 \mu \mathrm{m}$, distance Vh9/4 to $\mathrm{C} \alpha-\mathrm{Vh} 1$ to $\mathrm{C} \alpha>0.15 \mu \mathrm{m})$.

In order to assess the statistical significance of the difference in distances between proB cells and $\mathrm{CD} 8^{+} \mathrm{T}$ cells, we performed an ordinary ANOVA test using nonparametric methods, as most data did not fit a Gaussian distribution. Dunn's tests were performed for multiple comparison post-tests. In order to assess the statistical significance of the difference in looping observed between $\mathrm{RAG2}^{-/-}$pro B cells and $\mathrm{CD} 8^{+} \mathrm{T}$ cells, contingency tables were established (Supplementary Table S3). All statistical tests were performed using Graphpad's Prism version 4.0.

\section{Acknowledgments}

We thank Karine Monier, James Feramisco, and Steve McMullen for valuable help in 3D FISH techniques, image acquisition, and data analysis. We are grateful to Isaac Engel, Albert Westerman, and Maho Niwa for comments on the manuscript. C.E.S. was supported by a postdoctoral fellowship from the Canadian Institute of Health Research (CIHR). This work was supported by grants from the NIH to C.M.

\section{References}

Baxter, J., Merkenschlager, M., and Fisher, A.G. 2002. Nuclear organisation and gene expression. Curr. Opin. Cell Biol. 14: 372-376.

Bergman, Y. and Cedar, H. 2004. A stepwise epigenetic process controls immunoglobulin allelic exclusion. Nat. Rev. Immunol. 4: 753-761.

Carter, D., Chakalova, L., Osborne, C.S., Dai, Y.F., and Fraser, P. 2002. Long-range chromatin regulatory interactions in vivo. Nat. Genet. 32: 623-626.

Chevillard, C., Ozaki, J., Herring, C.D., and Riblet, R. 2002. A threemegabase yeast artificial chromosome contig spanning the C57BL mouse Igh locus. J. Immunol. 168: 5659-5666.

Chowdhury, D. and Sen, R. 2001. Stepwise activation of the immunoglobulin $\mu$ heavy chain gene locus. EMBO J. 20: 6394-6403.

Eastman, Q.M., Leu, T.M., and Schatz, D.G. 1996. Initiation of V(D)J recombination in vitro obeying the $12 / 23$ rule. Nature 380: $85-88$

Felsenfeld, G. and Groudine, M. 2003. Controlling the double helix. Nature 421: 448-453.

Fuxa, M., Skok, J., Souabni, A., Salvagiotto, G., Roldan, E., and Busslinger, M. 2004. Pax5 induces V-to-DJ rearrangements and locus contraction of the immunoglobulin heavy-chain gene. Genes \& Dev. 18: $411-422$.

Goebel, P., Janney, N., Valenzuela, J.R., Romanow, W.J., Murre, C., and Feeney, A.J. 2001. Localized gene-specific induction of accessibility to $\mathrm{V}(\mathrm{D}) \mathrm{J}$ recombination induced by E2A and early B cell factor in nonlymphoid cells. J. Exp. Med. 194: 645-656. 
Goebel, P., Montalbano, A., Ayers, N., Kompfner, E., Dickinson, L., Webb, C.F., and Feeney, A.J. 2002. High frequency of matrix attachment regions and cut-like protein $\mathrm{x} / \mathrm{CCAAT}$-displacement protein and B cell regulator of IgH transcription binding sites flanking Ig V region genes. J. Immunol. 169: 2477-2487.

Hesslein, D.G., Pflugh, D.L., Chowdhury, D., Bothwell, A.L., Sen, R., and Schatz, D.G. 2003. Pax5 is required for recombination of transcribed, acetylated, 5' IgH V gene segments. Genes \& Dev. 17: 37-42.

Ikawa, T., Kawamoto, H., Wright, L.Y., and Murre, C. 2004. Long-term cultured E2A-deficient hematopoietic progenitor cells are pluripotent. Immunity 20: 349-360.

Jones, J.M. and Gellert, M. 2004. The taming of a transposon: V(D)J recombination and the immune system. Immunol. Rev. 200: 233-248.

Jung, D. and Alt, F.W. 2004. Unraveling V(D)J recombination; insights into gene regulation. Cell 116: 299-311.

Kosak, S.T., Skok, J.A., Medina, K.L., Riblet, R., Le Beau, M.M., Fisher, A.G., and Singh, H. 2002. Subnuclear compartmentalization of immunoglobulin loci during lymphocyte development. Science 296: 158-162.

Mainville, C.A., Sheehan, K.M., Klaman, L.D., Giorgetti, C.A., Press, J.L., and Brodeur, P.H. 1996. Deletional mapping of fifteen mouse VH gene families reveals a common organization for three Igh haplotypes. J. Immunol. 156: 1038-1046.

Mombaerts, P., Iacomini, J., Johnson, R.S., Herrup, K., Tonegawa, S., and Papaioannou, V.E. 1992. RAG-1-deficient mice have no mature B and T lymphocytes. Cell 68: 869-877.

Ostermeier, G.C., Liu, Z., Martins, R.P., Bharadwaj, R.R., Ellis, J., Draghici, S., and Krawetz, S.A. 2003. Nuclear matrix association of the human $\beta$-globin locus utilizing a novel approach to quantitative real-time PCR. Nucleic Acids Res. 31: 3257-3266.

Romanow, W.J., Langerak, A.W., Goebel, P., Wolvers-Tettero, I.L., van Dongen, J.J., Feeney, A.J., and Murre, C. 2000. E2A and EBF act in synergy with the $\mathrm{V}(\mathrm{D}) \mathrm{J}$ recombinase to generate a diverse immunoglobulin repertoire in nonlymphoid cells. Mol. Cell 5: 343-353.

Schebesta, M., Heavey, B., and Busslinger, M. 2002. Transcriptional control of B-cell development. Curr. Opin. Immunol. 14: 216-223.

Seet, C.S., Brumbaugh, R.L., and Kee, B.L. 2004. Early B cell factor promotes B lymphopoiesis with reduced Interleukin 7 responsiveness in the absence of E2A. J. Exp. Med. 199: 1689-1700.

Shinkai, Y., Rathbun, G., Lam, K.P., Oltz, E.M., Stewart, V., Mendelsohn, M., Charron, J., Datta, M., Young, F., Stall, A.M., et al. 1992. RAG2-deficient mice lack mature lymphocytes owing to inability to initiate V(D)J rearrangement. Cell 68: 855-867.

Spicuglia, S., Kumar, S., Yeh, J.H., Vachez, E., Chasson, L., Gorbatch, S., Cautres, J., and Ferrier, P. 2002. Promoter activation by enhancerdependent and -independent loading of activator and coactivator complexes. Mol. Cell 10: 1479-1487.

Steen, S.B., Gomelsky, L., and Roth, D.B. 1996. The 12/23 rule is enforced at the cleavage step of $\mathrm{V}(\mathrm{D}) \mathrm{J}$ recombination in vivo. Genes Cells $\mathbf{1}$ : 543-553.

Tolhuis, B., Palstra, R.J., Splinter, E., Grosveld, F., and de Laat, W. 2002. Looping and interaction between hypersensitive sites in the active $\beta$-globin locus. Mol. Cell 10: 1453-1465.

Urbanek, P., Wang, Z.Q., Fetka, I., Wagner, E.F., and Busslinger, M. 1994. Complete block of early B cell differentiation and altered patterning of the posterior midbrain in mice lacking Pax5/BSAP. Cell 79: 901912.

Yancopoulos, G.D. and Alt, F.W. 1986. Regulation of the assembly and expression of variable-region genes. Annu. Rev. Immunol. 4: 339368.

Yancopoulos, G.D., Desiderio, S.V., Paskind, M., Kearney, J.F., Baltimore, D., and Alt, F.W. 1984. Preferential utilization of the most JH-proximal VH gene segments in pre-B-cell lines. Nature 311: 727-733. 


\section{Erratum}

Genes \& Development 19: 322-327 (2005)

Visualization of looping involving the immunoglobulin heavy-chain locus in developing B cells

Camil Sayegh, Suchit Jhunjhunwala, Roy Riblet, and Cornelis Murre

In the above-mentioned paper, the first author's middle initial was mistakenly omitted. The first author should be listed as Camil E. Sayegh. 


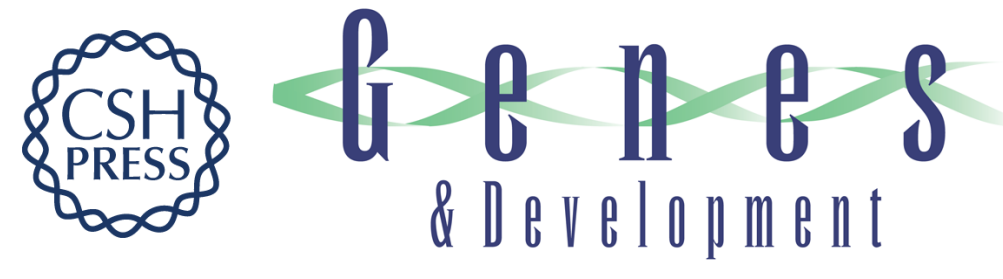

\section{Visualization of looping involving the immunoglobulin heavy-chain locus in developing B cells}

Camil Sayegh, Suchit Jhunjhunwala, Roy Riblet, et al.

Genes Dev. 2005, 19:

Access the most recent version at doi:10.1101/gad.1254305

\section{Supplemental http://genesdev.cshlp.org/content/suppl/2005/01/13/19.3.322.DC1 Material}

\section{Related Content}

References

Email Alerting Service

\section{License}

\section{Erratum}

Genes Dev. June , 2008 22: 1717

This article cites 28 articles, 9 of which can be accessed free at: http://genesdev.cshlp.org/content/19/3/322.full.html\#ref-list-1

Articles cited in:

http://genesdev.cshlp.org/content/19/3/322.full.html\#related-urls

Receive free email alerts when new articles cite this article - sign up in the box at the top right corner of the article or click here.

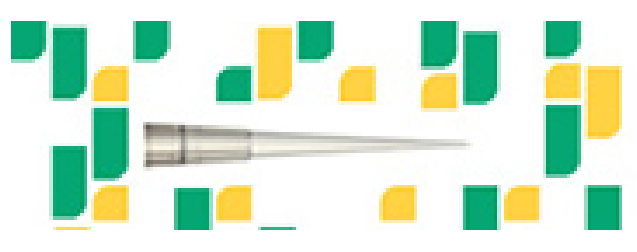

Focused on your science. 